\title{
Measuring the Impacts of Online Word-of-Mouth on Tourists' Attitude and Intentions to Visit Jordan: An Empirical Study
}

\author{
Abbas N. Albarq ${ }^{1}$ \\ ${ }^{1}$ School of Economics \& Administrative Science, Al Imam ibn Muhammad ibn Saud Islamic University, \\ Kingdom of Saudi Arabia
}

Correspondence: Abbas Albarq, School of Economics \& Administrative Science, Al Imam ibn Muhammad ibn Saud Islamic University, Riyadh, Saudi Arabia. Tel: 9-665-621-88878. E-mail: dr.abbasalbarq@yahoo.com

Received: October 5, 2013

Accepted: November 20, 2013

Online Published: December 23, 2013

doi: 10.5539/ibr.v7n1p14

URL: http://dx.doi.org/10.5539/ibr.v7n1p14

\begin{abstract}
Reduced consumer trust, both of organizations and advertising, has led to electronic word of mouth (e-WOM) becoming an increasingly popular way of obtaining competitive advantage. e-WOM is especially relevant with regard to tourism, specifically tourists' attitudes toward such destinations. This study explores the empirical and theoretical evidence regarding the causal e-WOM relationships between tourists' attitudes regarding specific destinations and actual intention to travel. In the context of visits to Jordan, we applied SEM technique to examine these relationships. A pre-validated questionnaire was distributed to a convenience sample with response rate of $97.3 \%$. The result revealed that e-WOM communications positively impact tourists' travel intentions and their attitudes toward Jordan as a destination, while a positive effect is found for the attitudes toward Jordan visit on their intention to travel. Managers of travel agency can consider various aspects of e-WOM to encourage tourists to participate in online travel communities and to build such communities, as this will foster trust in terms of visiting Jordan.
\end{abstract}

Keywords: e-WOM, tourists' attitudes, travel intention, SEM, Jordan

\section{Introduction}

From marketer perspective now days, Word-of-mouth (WOM) is a substantial subject and key player in marketing. After using a product or service, many consumers share their experiences with that product or service with their friends and family. The influence, and therefore, the effect of this relationship are very substantial. Park et al. (2011) argued that the strength of Word-of-mouth is greater than that of conventional advertising in terms of its ability to create negative or positive attitudes of consumers. The rapid development of the Internet has enabled consumers to easily share their opinions of products or services with a potentially wide audience. Several studies have shown that e-WOM affects consumers' attitudes regarding a wide variety of products and services. Some researchers have noted that one characteristic of e-WOM is that it has occurred within between people could have no relationship between each other or know with whom they are communicate (Sen \& Lerman, 2007). The popularity of virtual interactions among tourists has led some researchers to highlight the importance of online WOM in acquiring and retaining tourists in the era of e-commerce (Vermeulen \& Seegers, 2009). A study done by Compete (2007) revealed that around one-third of consumers are communicating with message boards, online communities, or forums before making online travel purchases because they believe that online reviews help them make their purchase decisions.

According to Gretzel and Yoo (2008) estimate, over seventy percent of travelers are considered online view from experienced traveler as major information resources when they decide to go abroad for pleasure travel. This statement agrees also by Forrester Research's (2006) who stated that online WOM a key player for traveler. Each year, the total amount of online travel purchases influenced by online reviews is in excess of US\$10 billion (Compete, 2007). An example of a website on which consumers share their travel-related opinions is tripadvisor.com, which describes itself as one of the largest sites for travel reviews, where updated continuously (tripadvisor.com, 2005).

Despite the large amount of marketing research conducted on e-WOM, none of it has focused on e-WOM specifically in the tourism industry or its impact on consumers' choice of tourism destination. The present study shows an empirical examination for the relationships among e-WOM and tourists' attitudes and travel intentions 
regarding Jordan. The way in which the Internet has facilitated this form of communication has increased the need to understand how e-WOM can impact consumers' decision-making processes (Park et al., 2011).

\section{Literature Review}

\subsection{Tourism Industry in Jordan}

Jordan is widely located as "Westernized" countries in the Arab World. It has become a popular destination for foreigners seeking to live, work, or study in that region (Westernized media in Jordan breaking old taboos, 2012). In 2011, 1.8 million tourists visited Amman (Jordan's capital city) and spent over $\$ 1.3$ billion there (Periodical Islamic Chamber Of Commerce \& Industry Magazine, 2012), making it the eighth-most visited city in the Middle East and Africa, and the ninth-highest recipient of international visitor spending. The entire Kingdom of Jordan received 8 million visitors in 2010 and $\$ 4.4$ billion in visitor expenditure (Periodical Islamic Chamber Of Commerce \& Industry Magazine, 2012). Traditionally one of the most politically stable countries in the region, Jordan has recently experienced a high level of economic growth, driven mainly by mining, tourism, and real estate. In 2012, tourism revenue represented 14 percent of Jordan's GDP and increased by approximately 17 percent each year between 2004 and 2010 (Ministry of Tourism \& Antiquities, 2012).

Tourism is an important part of Jordan's economy and the national government has made several attempts to accelerate the development of this segment. The Jordanian Tourism Board's National Tourism Strategy 20042010 is a strategic plan to boost the country's tourism industry. By 2014, the Jordanian Tourism Board aimed to double its tourism receipts to approximately JOD 1.3 billion, and it also forecast that more than 51,000 new jobs should have been created within the tourist industry by 2012 (see Table 1). The national government has recently cut sales tax on hotels from 14 percent to 8 percent in an effort to protect the country's tourism industry from the impact of the global recession. The tourism ministry also announced that it would ease entry requirements for tourists from India and China.

Table 1. Monthly beds night/arrivals at classified hotels by country group, 2013

\begin{tabular}{|c|c|c|c|c|c|}
\hline Month & & & & & \\
\hline \multicolumn{6}{|l|}{ Tourists' region of origin } \\
\hline \multirow{2}{*}{ African Countries } & Nights & 1266 & 1556 & 3767 & 6589 \\
\hline & Arrivals & 571 & 978 & 2263 & 3812 \\
\hline \multirow{2}{*}{ American Countries } & Nights & 25,336 & 26,380 & 37,017 & 88,733 \\
\hline & Arrivals & 15,418 & 15,442 & 21,711 & 52,571 \\
\hline \multirow{2}{*}{ Arab countries } & Nights & 113,998 & 102,365 & 116,720 & 333,083 \\
\hline & Arrivals & 44,182 & 46,093 & 51,990 & 142,265 \\
\hline \multirow{2}{*}{ Asia \& Pacific countries } & Nights & 22,027 & 24,285 & 31,710 & 78,022 \\
\hline & Arrivals & 13,317 & 16,132 & 17,802 & 47,251 \\
\hline \multirow{2}{*}{ European countries } & Nights & 73,530 & 81,702 & 137,815 & 293,047 \\
\hline & Arrivals & 32,769 & 37,712 & 68,747 & 139,228 \\
\hline \multirow{2}{*}{ Jordanian } & Nights & 37,149 & 59,299 & 81,730 & 208,178 \\
\hline & Arrivals & 35,799 & 34,527 & 49,058 & 119,384 \\
\hline \multirow[b]{2}{*}{ Total } & Nights & 303,306 & $\mathbf{2 9 5 , 5 8 7}$ & 408,759 & $1,007,652$ \\
\hline & Arrivals & 142,056 & 150,884 & 211,571 & 504,511 \\
\hline
\end{tabular}

* Source: Ministry of Tourism \& Antiquities (Data up to 31/3/2013).

\subsection{Word of Mouth from a Marketing Perspective}

A lot of scholar have mentioned in the literature WOM as a key player tool in marketing concept. Sernovitz et al. (2009) noted that people enjoy talking about products and services they have consumed, and they also discuss 
the producers and providers services or could provide product. People sometimes often feel proud about consuming a particular product, while other people suggest that others do not consider buying a certain product. Therefore, word of mouth marketing is about earning the positive comments from consumers. Some researchers, such as Tucker (2011), consider WOM to be a key to an organization's success. Tucker (2011) added that consumers, as a whole, are often untrusting of the producer's own advertising, and much more trusting of other consumers.

Because WOM can be positive or negative, some researchers have linked the type of WOM to the satisfaction level. Steinkuehler and Williams (2006) proposed three main theories related to consumers engaging in WOM:

1) Satisfied customers share their opinions with others for several reasons, including the following:

- To draw attention to themselves

- To reduce cognitive conflict

- To avoid being negative

- To appear knowledgeable to others

- They like to help others.

2) Dissatisfied consumers engage in WOM for the following reasons:

- To warn others

- To vent their dissatisfaction.

- To reduce anxiety

3) Exceedingly satisfied with those are dissatisfied will be most extreme and therefore have the greatest impact.

WOM communication is an increasingly important topic in marketing these days, as consumers' behavior is becoming increasingly immune to traditional advertising and other marketing communications. Essentially, e-WOM is the same tradition relationship between two or more based on oral, person-to-person communication as a tool, but in e-WOM internet is the based tool for this communication. Obviously, e-WOM is different in that it involves communication over the internet rather than verbal or face-to-face communication.

\subsection{Online Word of Mouth and Tourism Industry}

The Internet has given consumers many more ways to acquire product information, particularly by considering the opinions of other consumers, and provided opportunities for consumers to share their own consumption-related opinions (Hennig et al., 2004). Recent tourism-related research has shown the influence have a mojor impact on tourism-related products and services in several countries (Litvin et al., 2008). Bone (1992) argued that e-WOM occurs during the consumption of a product, since individuals are simply sharing their thoughts. Anderson (1998), on the other hand, implied that e-WOM can be positive, neutral, or negative. Several researchers have argued that e-WOM is more powerful than more traditional forms advertising (Tucker, 2011).

Some reports have indicated that the number of visitors who used online to review the other opinion from other experienced consumers in travel for such destination each year runs into the hundreds of millions (Tripadvisor.com, 2006). Up to 84 percent of these visitors are influenced by online and effect their plan and decision for travel (Travelindustrywire.com, 2007). This agrees also by Goldenberg et al. (2001) emphasized that WOM from other consumers has a strong influence on consumer decision-making processes. In (2008) Gretzel and Yoo revealed that readers often perceive other travelers' reviews to be more enjoyable, and trustier than advertisement offered by traveler agencies.

The fact that online reviews from travelers are important information sources, both for travelers and tourism companies, has led researchers to use sophisticated technologies in attempts to analyze and understand online traveler reviews (Ye et al., 2011; Jalilvand et al., 2012). Zhou and Lai (2009) indicate that the amount of online users and blogs by tourists has a significant correlation with the actual number of tourists a destination receives, although there was no significant correlation between the number of actual tourists and the size of travel adviser. Opinions regarding the power of e-WOM vary widely, and most of the prior literature is based on surveys that asked respondents to report the extent to which online reviews impacted their travel-related decisions (Gretzel \& Yoo, 2008; Vermeulen \& Seegers, 2009). Recent tourism research, in several countries, has shown how much influence positive and negative e-WOM has on tourism products. For example, Morgan, Pritchard et al. (2003) research in a New Zealand context found passive, negative or unfavorable online WOM have a very strong negative impact on a destination's image.

In Dennis et al.'s (2009) conceptual model of e-consumers' behavior, a positive attitude towards an e-retailer will influence the intention to purchase a product or service from that e-retailer. This concurs with Vermeulen and 
Seegers (2009) found that increasing in online intention to review other opinion consumer toward such service or product increased and improve the awareness for travelers' attitudes. Castaneda et al.'s (2009) study examined how tourists' attitudes towards certain websites and the Internet in general can help explain attitudes regarding brands and consumer behavior. With these findings, we anticipate that:

\section{H1: e-WOM has a positive effect on tourists' attitudes toward destinations. \\ H2: e-WOM has a positive effect on travel intention.}

\subsection{Attitudes toward Destination}

Attitude is important due to the power and the ability to predict specific behaviors (Kraus, 1995). Attitude toward a certain behavior has been defined as the level or the stand can represents person's feeling as appropriate or not (Ajzen, 1991), an individual with a more favorable attitude towards a behavior will have a stronger intention to act that behavior (Ajzen, 1991). In the context of the present study, the behavior in question is the intention to travel such destination and the attitude is the consumer's attitude toward the relevant destination. Based on the opinions of the above-mentioned researchers, we anticipate that:

\section{H3: The attitudes of tourist toward Jordan visit positively effect on travel intention.}

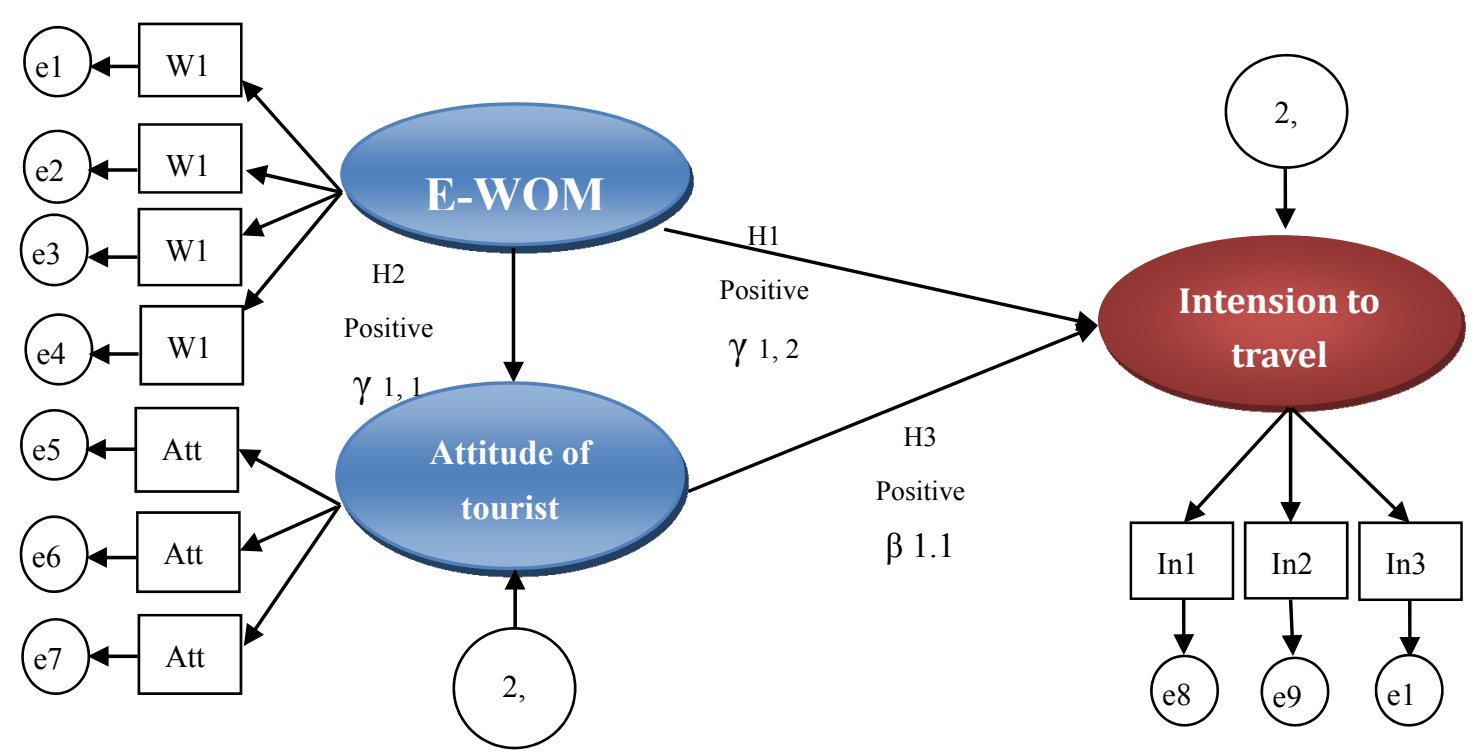

Figure 1. The proposed model (adopted by Jalilvand and Samiei, 2012)

\section{Method}

Our empirical study was conducted in Amman, which is a popular Jordanian tourism destination. The study's target population was international visitors. Accurate data was not available regarding the size and location of this population, which meant that it was not possible to use probabilistic sampling techniques. Using convenience method for data collection, this study was based. Piloted questionnaire was distributed to 302 participants with a response rate of $97.3 \%$. We gathered our data between June and October, 2011 and administered the questionnaire to the respondents personally. Table 3 shows the sample profile.

\subsection{Measurement Instrument}

The study's main goal was to investigate the influence that e-WOM has on the attitudes of tourists towards destinations and intentions to travel. With this in mind, we modified certain existing scales. The questionnaire had four parts. The purpose of the first part was to identify the socio-demographic characteristics of the sample, which was done using such items as gender, level of education, age, purpose of travel, primary residence, and previous visits to Jordan. The second part involved questions about e-WOM. The third part dealt with tourists' attitudes regarding Jordan; and the fourth and final part captured travel intentions. We followed Bambauer-Sachse and Mangold's (2011) six-item measurement of e-WOM. We measured attitude using the modified scales that Gamble et al. (2009) developed, which included such items as very bad/very good, very unpleasant/very pleasant, very worthless/very valuable. Then, we measured travel intention by modifying and 
using a three-item scale that Jalilvand and Samiei (2012) developed. Our final questionnaire included 12 items and used a 7-point numerical Likert-type scale from strongly disagree (1) to strongly agree (7).

\subsection{Data Analysis}

We tested the inter-relationships between the research variables using structural equation model (SEM) (version 14) and we also conducted a confirmatory factor analysis (CFA) on measurement and structural models. CFA specifies which indicators define each latent construct (Hair et al., 2006). We evaluated different GOF indices, such as the chi-square (w2), the standardized root means square residual (SRMR), the normed chi-square statistic (w2/df), the (RMSEA), the comparative fit index (CFI), and the goodness-of-fit index (GFI). The (w2/df) is below 3.0 (Abbas et al., 2013), while the SRMR value in a well-fitting model should be lower than 0.05 (Byrne, 1998). An less than 0.08 value for represent good fit (Abbas et al., 2013), while a good fit is indicated by values below 0.06 (Hair et al., 2006). The GFI is an absolute index that measures the sample data's covariance (Byrne, 1998). A CFI 0.95 indicates a good-fitting model; this value takes the sample size into account (Hair et al., 2006; Abbas et al., 2013). In order to measure scale reliability and validity, we used internal consistency measures (Cronbach's alpha) and tested discriminant validity and convergent validity.

\section{Results}

The overall response rate was $97.3 \%$. Table 2 shows our results after analyzing the demographic data according to the questionnaire.

Table 2. Results of the analysis of demographic data

\begin{tabular}{|c|c|c|c|}
\hline Demographic Variables & & Frequency & Valid Percent \% \\
\hline \multirow{2}{*}{ Gender } & Male & 201 & 68.3 \\
\hline & Female & 93 & 31.7 \\
\hline \multirow{7}{*}{ Primary residence } & Arabian Gulf & 53 & 18.0 \\
\hline & France & 48 & 16.3 \\
\hline & Britain & 38 & 12.9 \\
\hline & Italy & 47 & 16.0 \\
\hline & Germany & 36 & 12.2 \\
\hline & USA \& Canada & 45 & 15.3 \\
\hline & Others & 27 & 9.3 \\
\hline \multirow{4}{*}{ Age } & under 25 & 41 & 14.0 \\
\hline & $26-35$ & 84 & 28.6 \\
\hline & $36-45$ & 104 & 35.4 \\
\hline & 46 and above & 65 & 22.0 \\
\hline \multirow{3}{*}{ Education } & Primary & 38 & 13.0 \\
\hline & Secondary & 118 & 40.0 \\
\hline & University & 138 & 47.0 \\
\hline \multirow{4}{*}{ Number of visits } & First time & 98 & 33.3 \\
\hline & 2 times & 91 & 31.0 \\
\hline & $3-5$ times & 57 & 19.3 \\
\hline & Over 5 times & 48 & 16.4 \\
\hline \multirow{4}{*}{ Purpose of visit } & Holiday & 184 & 62.2 \\
\hline & Medical & 47 & 16.0 \\
\hline & Business & 34 & 11.6 \\
\hline & Others & 29 & 10.2 \\
\hline
\end{tabular}


Table 3 shows the indicator loadings, Cronbach's alpha and AVE values of each construct. For all factors, the Cronbach's alpha coefficients ( 0.70 and above), and ranged from 0.830 (e-WOM) to 0.869 (travel intention), while the AVE values are all (0.05 and above), and range from 0.782 (attitude toward travel such destination) to 0.799 (e-WOM).

Table 3. Descriptive statistics for all items of the questionnaire

\begin{tabular}{lcc}
\hline Latent variable & $\boldsymbol{\alpha}$ & AVE \\
\hline Electronic word of mouth (e-WOM) & 0.830 & 0.782 \\
Attitude: & 0.841 & 0.787 \\
Intention & 0.869 & 0.799 \\
\hline
\end{tabular}

Table 4 shows the correlation coefficients of the study's constructs; e-WOM, travel intention, tourists' attitudes, and the correlations were all significant at the $\mathrm{p} \leq 0.01$ level. All of the squared correlations were less than the AVE value for each factor, representing good discriminant validity.

Table 4. Correlations of constructs

\begin{tabular}{lcc}
\hline Latent variables & e-WOM & Attitude \\
\hline Electronic word of mouth & - & $0.548^{*}$ \\
Attitude toward destination & $0.548^{*}$ & - \\
Intention to travel & $0.601 *$ & $0.601 *$ \\
\hline
\end{tabular}

$* \mathrm{p} \leq 0.01$.

We then used AMOS 17.0 Graphics for the structural model where also to test the hypothesized relationship between the constructs. We used the results of the maximum likelihood (ML) method to compare structure coefficients between latent variables; as Table 5 shows, the estimation indicated that the model goodness-of-fit (GOF) was good.

Table 5. Hypothesized model (model fit statistics)

\begin{tabular}{|c|c|c|c|}
\hline Measures & & Fit Indices & Threshold Values \\
\hline \multirow{3}{*}{ Absolute Fit Level } & RMSEA & 0.048 & Less than 0.08 \\
\hline & GFI & 0.991 & 0.90 and Above \\
\hline & P-Value & 0.059 & P- Value $\geq 0.05$ \\
\hline \multirow{4}{*}{ Incremental Fit Level } & AGFI & 0.903 & 0.90 and Above \\
\hline & CFI & 0.981 & 0.90 and Above \\
\hline & NFI & 0.964 & 0.90 and Above \\
\hline & CFI & 0.979 & 0.90 and Above \\
\hline \multirow{2}{*}{ Parsimonious Fit Level } & $\mathrm{CMIN} / \mathrm{df}$ & 1.454 & Less than 2.0 \\
\hline & $\operatorname{SMC}\left(\mathrm{R}^{2}\right)$ & 0.698 & Bigger better \\
\hline
\end{tabular}

Table 6 shows the parameter estimates for the relationships between each independent variable and the dependent variable for which the three hypotheses were tested. Our results provided support for the relationships that we hypothesized among attitude, e-WOM, and intention to travel. As a result, hypotheses $\mathrm{H} 1, \mathrm{H} 2$, and $\mathrm{H} 3$ were supported. If the C.R. of the estimated covariance among the latent variables was greater than \pm 1.96 , we assessed the variables as being significant [the " + " denotes a positive effect and the " - " denotes a negative effect]. All links were both significant and positive. 
Table 6. Regression weight for the results of research model $(\mathrm{n}=189)$

\begin{tabular}{llcccc}
\hline Exogenous variable & Endogenous variable & Es. & SE & CR & p-value \\
\hline e-WOM & Attitude of traveler toward destination & 0.638 & 0.046 & 13.960 & $* *$ \\
e-WOM & Intention to travel & 0.858 & 0.051 & 16.788 & $* *$ \\
Attitude of traveler toward destination & Intention to travel & 0.274 & 0.041 & 6.696 & $*$ \\
\hline
\end{tabular}

** $\mathrm{p}<0.001$ level (two-tailed); $* \mathrm{p}<0.05$ level (two-tailed).

\section{Discussion}

We sought to identify the destination choice processes of the respondents within the concept of internet communications. In our model, the main determinants of the tourists' travel intention were e-WOM and the tourists' attitudes toward the destination. We then hypothesized and validated the impacts of e-WOM using two separate cases: the influence of e-WOM on (a) travel intention and (b) attitude toward destination. Our two hypotheses related to the impact that e-WOM has on the attitudes and travel intentions of tourists. Our third hypothesis referred to the impact that tourists' attitudes had on their travel intentions. We then conducted an experimental survey using newly developed measures that used SEM to analyze 294 survey responses. Ultimately, all three hypotheses were supported, which is agreeing by several previous research mentioned in the literature review. Fakharyan et al. (2012) proposed that e-WOM have a positive influence on tourists' attitudes and travel intentions regarding certain destinations. Furthermore, there is a significant association between attitudes toward these destinations and intention to travel. This sentiment is similar to that of Jalilvand et al. (2012), who found that online WOM accurately reflects consumers' travel intentions towards a destination. Barbara and Vesna's (2006) model shows that satisfied tourist tend to use e-WOM to communicate with other persons their experiences nevertheless positively or negatively and tend to travel to such destinations again.

The results of the present study have several implications with practical importance. Tourists who articulate e-WOM provide an actual situation have faced by them in such destination where can transfer these experiences by telling other people through the online net and provide a base for people who are searching information for more understanding the destination's selected. Tourists who decide to travel to a certain destination may come to rely on e-WOM can have (Lewis \& Chambers, 2000). Indeed, manager need realized which types of experience are likely to trigger positive e-WOM. When tourists have a positive experience of a service, product, or other resource provided by a destination, they may visit again and communicate positive e-WOM regarding the destination to other potential tourists. If a destination provides an enjoyable travel experience and excellent services, this is likely to encourage altruistic behavior from tourists toward the destination and to arouse a psychological desire among tourists to share their positive experience with others online.

Managers can also help build online tourism communities. The main forum for travelers to exchange information online is in the community of the tourism service's website; as travelers may communicate freely about their own travel feelings and factors such as the service provided by a restaurant or hotel. The e-WOM information in such communities differs from that on the tourist enterprise's own website in that they facilitate multi-directional information exchange and generally lack commercial motivation (Zhu \& Lai, 2009). These are reasons why e-WOM has greater influence on the decisions of tourists than the tourism enterprise's own websites. Therefore, a tourism enterprise should establish discussion communities on their websites where tourists can conveniently exchange their opinions and promote the tourism enterprise through e-WOM. Managers should encourage travelers to participate in the online community because a high number of reviews of a destination will lead to more information about the destination being disseminated among potential tourists, which will increase the likelihood of them selecting that destination. Given that e-WOM as a key player as the source of data or information could for tourists' perceptual/cognitive evaluations, tourism services should identify ways to facilitate tourists' use of e-WOM. The shift in consumer's behavior - that is, the construction of a shield against traditional methods of marketing communications - has made it even more important for marketing communication to understand e-WOM communication. Marketers in tourism sector should recognize that their potential consumers are increasingly using online resources and are therefore should consider it seriously in their marketing strategy.

\section{Conclusion}

This study has examined the impact that e-WOM has on tourist attitudes and travel intentions. Our findings have shown that the impact of e-WOM on tourists' attitude towards such destinations like Jordan, and their 
consequent travel intentions, is significant. We considered how e-WOM impacts attitudes regarding destinations and travel intentions, which enabled us to identify the decision-making process and, in so doing, offer a rationale for tourists' travel behavior with regard to online communications. The present study has certain limitations. Firstly, although we have attempted to reach some conclusions the convenience sampling method in the questionnaire meant that we could not consider the sample for all tourists. Secondly, our study was conducted only in Amman, so future studies should be conducted in other parts of Jordan. Another area for future study is to identify the factors that may affect e-WOM, as well as the new dynamics and behavioral implications on travel behavior that e-WOM has created.

\section{Acknowledgements}

Thanks to all persons who assist in distributing questionnaires and special thanks to Queen Alia Airport staff in Amman who support me to distribute and collect the questionnaires used in the studies.

\section{References}

Abbas, A., Suleiman, A., \& Almualla, A. (2013). Using structural equation modeling for beginner. Jordan, Amman: Ithraa, Inc.

Anderson, E., \& Weick, B. (1989). Determinants of countinuity in conventional industrial channel dyads. Journal of Marketing Science, 8(4), 310-323. http://dx.doi.org/10.1287/mksc.8.4.310

Ajzen, I. (1991). The theory of planned behavior. Organ. Behav. Hum. Decis. Process, 50(2), 179-211. http://dx.doi.org/10.1016/0749-5978(91)90020-T

Byrne, B. M. (1998). Structural Equation Modeling with LISREL, PRELIS, and SIMPLIS: Basic Concepts, Applications, and Programming. Mahwah, NJ: Lawrence Erlbaum Associates.

Barbara, Z., \& Vesna, Z. (2006). Examination of co-operative norms, beliefs in interpersonal trustworthiness, complementary capabilities and realized competitive advantages in business-to-business relationships. Economic and Business Review for Central and South, 8(1), 11-19.

Bone, P. F. (1992). Eterminants of word-of-mouth communications during product consumption. Advances in Consumer Research, 19(4), 579-583. http://www.acrwebsite.org/search/view-conference-proceedings.aspx?Id=7359

Castaneda, J. A., Rodriguez, M. A., \& Luque, T. (2009). Attitudes' hierarchy of effects in online user behavior. Online Inform. Rev, 33(1), 7-21. http://dx.doi.org/10.1108/14684520910944364

Compete, Inc. (2007). Consumer Generated Content: Learning from Travel Innovators. Retrieved May 21, 2013, from

https://media.competeinc.com/med/uploads/files/traveltrends_consumer_generated_travel_content.html

Dennis, C., Merrilees, B., Jayawardhena, C., \& Wright, L. (2009), E-consumer behavior. European Journal of Marketing, 43(10), 1121-1139. http://dx.doi.org/10.1108/03090560910976393

Fakharyan, M., Jalilvand, M., Elyasi, M., \& Mohammadi, M. (2012). The influence of online word of mouth communications on tourists' attitudes toward Islamic destinations and travel intention: Evidence from Iran. African Journal of Business Management, 6(38), 10381-10388. http://dx.doi.org/10.5897/AJBM12.628

Forrester, S. (2006). The State Of Retailing Online: The 9th Annual Shop.org Study. Published by Shop.org, June 2006. Rrieved June 21, 2013, from http:// www.clickz.com/3611181

Gretzel, U., \& Yoo, K. (2008). Use and impact of online travel reviews. In O'Connor, P., Hopken, W., \& Gretzel, U. (Eds.), Information and communication technologies in tourism (pp. 35-46). New York: Springer-Verlag.

Goldenberg, J., Libai, B., \& Muller, E. (2001). Talk of the network: A complex systems look at the underlying process of word-of-mouth. Journal of Marketing Letter, 12(3), 211-223. http://dx.doi.org/10.1023/A:1011122126881

Hair, J., Black, W., Babin, B., Anderson, R., \& Tatham, R. (2006). Multivariate data analysis (6th ed.). Upper Saddle River, New Jersey: Pearson Education, Inc.

Thorsten, H. T., Kevin, P. G., Gianfranco, W., \& Dwayne, D. G. (2004). Electronic Word-of-Mouth via Consumer-Opinion Platforms: What Motivates Consumers to Articulate Themselves on the Internet? Journal of Interactive Marketing, 18(1), 38-52. http://dx.doi.org/10.1002/dir.10073

Jalilvand, M. R., \& Samiei, N. (2012). The Effect of Word of Mouth on Inbound Tourists Decision for Travelling to Isfahan as a Tourism Destination in an Islamic Republic. Journal of Islamic Marketing, 3(1), 12-26. 
http://dx.doi.org/10.1016/j.jdmm.2012.10.001

Litvin, S. W., Goldsmith, R. E., \& Pan, B. (2008). Electronic word-of-mouth in hospitality and tourism management. Tourism Manage, 29(3), 458-468. Retrieved from http://www.slideshare.net/JanKietzmann/2013-e-wom-jpa http://dx.doi.org/10.1016/j.tourman.2007.05.011

Lewis, R. C., \& Chambers, R. E. (2000). Marketing leadership in hospitality: Foundations and practices. New York: Wiley.

Morgan, N. A., \& Rego, L. L. (2006). The value of different customer satisfaction and loyalty metrics in predicting business performance. Marketing Science, 25(5), 426-439. http://dx.doi.org/10.1287/mksc. 1050.0180

Ministry of Tourism \& Antiquities Jordan. (2012). Retrieved 28 August, 2013, from http://www.tourism.jo/en/

Pan, B., MacLaurin, T., \& Crotts, J. (2007). Travel blogs and the implications for destination marketing. Journal Travel Res, 46(1), 35-45. http://dx.doi.org/10.1177/0047287507302378

Park, Y. A., \& Gretzel, U. (2007). Success Factors for Destination Marketing Web Sites: A Qualitative Meta-Analysis. Journal Travel Res, 46(1), 46-63. http://dx.doi.org/10.1177/0047287507302381

Periodical Islamic Chamber Of Commerce \& Industry Magazine. (2012). Chambermag.com. Retrieved 14 April, 2013 from http://chambermag.com/en/

Sernovitz, A. (2009). Word of Mouth Marketing: How Smart Companies Get People Talking (Revision and Updated ed.). New York: Kaplan Publishing.

Sen, S., \& Lerman, D. (2007). Why are you telling me this? An examination in to negative consumer reviews on the web. Journal of Interactive Marketing, 21(4), 76-94. http://dx.doi.org/10.1002/dir.20090

Steinkuehler, C. A., \& Dmitri, W. (2006). Where Everybody Knows Your (Screen) Name: Online Games as 'Third Places'. Journal of Computer-Mediated Communication, 4(11), 885-909. doi/10.1111/j.1083-6101.2006.00300.x/full

Tucker, T. (2011). Online word of mouth: Characteristics of Yelp.com reviews. The Elon Journal of Undergraduate Research in Communications, 2(1), 37-42.

Vermeulen, I. E., \& Seegers, D. (2009). Tried and tested: The impact of online hotel reviews on consumer consideration. Tourism Manage Journal, 30(1), 123-127. http://dx.doi.org/10.1016/j.tourman.2008.04.008

Westernized media in Jordan breaking old taboos. (2013). Retrieved 19 May, 2013 from http://rt.com/news/media-jordan-breaking-taboos/

Ye, Q., Law, R., Gu, B., \& Chen, W. (2011). The influence of user-generated content on traveler behavior: An empirical investigation on the effects of e-word-of-mouth to hotel online bookings. Comput. Hum. Behav, 27(4), 634-639. http://dx.doi.org/10.1016/j.chb.2010.04.014

Zhou, M., \& Lai, S. (2009). A study about the WOM influence on tourism destination choice. Paper presented at the International Conference on Electronic Commerce and Business Intelligence (ECBI), 6-7 June, Beijing, China. Retrieved from http://ieeexplore.ieee.org/stamp/stamp.jsp?arnumber $=05189500$

Zhu, M., \& Lai, S. (2009). A study about the WOM influence on tourism destination choice. In Paper presented at the international conference on Electronic Commerce and Business Intelligence (ECBI). Retrieved 19 June, 2013 from http://ieeexplore.ieee.org/stamp/stamp.jsp? number $=05189500 \mathrm{~S}$

\section{Copyrights}

Copyright for this article is retained by the author(s), with first publication rights granted to the journal.

This is an open-access article distributed under the terms and conditions of the Creative Commons Attribution license (http://creativecommons.org/licenses/by/3.0/). 